\title{
Analisis pendapatan pedagang kaki lima di Kota Jambi (studi kasus pedagang kaki lima di Jalan Jenderal Basuki Rahmat sampai H. Agus Salim Kecamatan Kota Baru)
}

\author{
*Panggno Septiawan; Rahma Nurjanah; Candra Mustika
}

Prodi Ekonomi Pembangunan, Fakultas Ekonomi dan Bisnis, Universitas Jambi

*E-mail korespondensi: spangno@gmail.com

\begin{abstract}
This study aims: 1) To find out and analyze the socio-economic characteristics of street vendors on Jalan Basuki Rahmat until General H. Agus Salim; 2) To find out and analyze what factors influence the income of street vendors on Jalan Basuki Rahmat until Jenderal H. Agus Salim by using multiple linear regression analysis tools. Based on the analysis of the characteristics of street vendors who are respondents according to the average age of 33 years, the highest sex is male, the most marital status is married, the number of family dependents is 3 dependents, according to the highest level of education, namely high school, the length of hours work that is 8 hours working time in a day, selling as a main job, average fixed capital of Rp. 2,212,000, operating capital with an average of Rp. 250,000 per day and for an average income of Rp. 3,376,000 per month. Based on the regression results indicate that the variables of capital, age, and working hours have a significant effect on the income of street vendors.
\end{abstract}

Keywords: Income, Capital, Age, Working Hours, Education Level.

\begin{abstract}
Abstrak
Penelitian ini bertujuan untuk: 1) Untuk mengetahui dan menganalisis karakteristik sosial ekonomi pedagang kaki lima di Jalan Jenderal Basuki Rahmat sampai H. Agus Salim; 2) Untuk mengetahui dan menganalisis faktor-faktor apa yang mempengaruhi pendapatan pedagang kaki lima di Jalan Jenderal Basuki Rahmat Sampai H. Agus Salim dengan menggunakan alat analisis regresi linier berganda. Berdasarkan analisis karakteristik pedagang kaki lima yang menjadi responden menurut umur rata-rata 33 tahun, jenis kelamin yang terbanyak yaitu laki-laki, status perkawinan terbanyak yaitu menikah, jumlah tanggungan keluarga sebesar 3 tanggungan, menurut tingkat pendidikan jumlah terbanyak yaitu SMA, dari lamanya jam kerja yaitu 8 jam waktu bekerja dalam sehari, berjualan sebagai pekerjaan utama, rata-rata modal tetap sebesar Rp. 2.212.000, modal operasional dengan rata-rata sebesar Rp. 250.000 perhari dan untuk pendapatan rata-rata Rp. 3.376 .000 perbulan. Berdasarkan hasil regresi menunjukkan bahwa variabel modal, umur, dan jam kerja berpengaruh signifikan terhadap pendapatan pedagang kaki lima.
\end{abstract}

Kata Kunci: Pendapatan, Modal, Umur, Jam Kerja, Tingkat Pendidikan. 


\section{PENDAHULUAN}

Banyak bidang informal yang berpotensi untuk diangkat dan digali menjadi salah satu bidang usaha yang menghasilkan keuntungan dan income keluarga sekaligus dapat menyerap tenga kerja. Usaha berdagang merupakan salah satu alternatif lapangan kerja informal, yang ternyata banyak menyerap tenaga kerja, seperti pedagang informal di Kota Baru Kota Jambi, Pendapatan pedagang informal dapat menjadi tumpuan pendapatan keluarga. Pada umumnya para pedagang mempunyai tujuan utama mendapatkan laba tertentu (mungkin maksimal) dan mempertahankan atau semakin berusaha meningkatkannya.

Pembangunan merupakan suatu proses perubahan yang berlangsung secara sadar, terencana dan berkelanjutan dengan sasaran utamanya adalah untuk meningkatkan kesejahteraan hidup manusia atau masyarakat suatu bangsa. Ini berarti bahwa pembangunan senantiasa beranjak dari suatu keadaan atau kondisi kehidupan yang kurang baik menuju suatu kehidupan yang lebih baik dalam rangka mencapai tujuan nasional suatu bangsa (Kamaluddin, 1999).

Usaha sektor informal dalam perkembangannya yang semakin luas dan nyata perlu dibina dan dilindungi agar tumbuh menjadi unsur kekuatan ekonomi. Dalam usaha perkembangan usaha sektor informal sangat diperlukan peranan pemerintah. Dalam hal ini pemerintah harus selalu berupaya untuk mendorong dan menciptakan iklim usaha yang kondusif agar usaha kecil tersebut dapat terus tumbuh dan berkembang dengan baik. Dengan demikian, usaha kecil akan menjadi kekuatan ekonomi yang tangguh dan mandiri serta dapat memperkuat struktur perekonomian nasional sehingga usaha kecil benar-benar menjadi tulang punggung perekonomian nasional (Damayanti, 2011).

Berdasarkan data dari Badan Pusat Statistik (2016) banyak para pekerja yang sebelumnya bekerja sektor formal, lari ke sektor informal. Hal ini membuat sektor informal menguat tinggi. Berdasarkan identifikasi tersebut, maka pada Februari 2015 penduduk Indonesia yang bekerja di sektor formal mencapai 41,72\% dan di kegiatan informal mencapai 57,94\%. Dibading kondisi Februari 2015, presentase pekerja informal bertambah dari 57,94\% pada Februari 2015 menjadi 58,28\% di Februari 2016.

Umur sangat berpengaruh terhadap pendapatan karena semakin tua umur istri, maka produktifitasnya semakin menurun dan kondisi fisiknya semakin lemah sehingga tidak mampu menyumbangkan pendapatan dalam keluarga (Sudarmini, 2006). Menurut Marchaeni dan Manuati (2004), orang yang berpendidikan lebih tinggi mulai dengan pendapatan yang lebih rendah, tapi dengan cepat menyalip mereka yang memiliki pendidikan yang lebih rendah. Artinya, pedagang perempuan yang mempunyai pendidikan lebih tinggi akan mampu meningkatkan pendapatannya.

Berdasarkan latar belakang sebelumnya, pedagang kaki lima di Kota Baru Kota Jambi pada umumnya bekerja untuk menghasilkan pendapatan untuk membantu keluarganya. Diduga ada beberapa faktor yang mempengaruhi pendapatan pedagang kaki lima makanan di Kota Baru. Salah satu diantaranya adalah modal, umur, tingkat pendidikan dan jam kerja. Dalam hal lamanya jam kerja, biasanya pedagang yang mempunyai jumlah jam kerja lebih lama, maka pendapatannya akan lebih maksimum. Sugeng (2009), menyimpulkan bahwa jam kerja berpengaruh terhadap pendapatan perempuan dalam perekonomian rumah tangga. Semakin lama jam kerja perempuan, maka semakin banyak hasil yang diterima sehingga kebutuhan keluarga bisa terpenuhi.

Berdasarkan masalah tersebut, peneliti merumuskan tujuan penelitian sebagai berikut: 1) Untuk mengetahui dan menganalisis karakteristik sosial ekonomi pedagang kaki lima di di Jalan Basuki Rahmat Sampai Jenderal H. Agus Salim; 2) Untuk 
mengetahui dan menganalisis faktor-faktor apa yang mempengaruhi pendapatan pedagang kaki lima yang menjual makanan dan minuman di Jalan Jendral Basuki Rahmat sampai Jenderal H. Agus Salim Kecamatan Kota Baru.

\section{METODE}

Adapun jenis penelitian yang digunakan dalam penelitian ini adalah metode survei. Metode survei adalah penelitian yang mengambil sampel dari populasi dengan menggunakan kusioner sebagai alat pengumpul data dimana peneliti langsung ke lokasi penelitian untuk mengumpulkan data serta fakta dari gejala-gejala yang ada untuk mencari keterangan keterangan secara faktual (Umar, 2002).

Definisi metode analisis deskriptif menurut Sugiyono (2013) adalah penelitian yang dilakukan untuk mengetahui nilai variabel mandiri, baik satu variabel atau lebih (independen) tanpa membuat perbandingan, atau menghubungkan dengan variabel yang lain.Metode analisis deskriptif ini menggunakan kuisioner kepada responden dengan tujuan untuk mengetahui data karakteristik sosial dan ekonomi PKL makanan yaitu umur, jenis kelamin, status perkawinan, jam kerja, tingkat pendidikan, pendapatan, dan modal.

Menurut Sukirno (2005), metode penelitian kuantitatif dapat diartikan sebagai metode penelitian yang berlandaskan pada filsafat positivisme, digunakan untuk meneliti pada populasi atau sampel tertentu, teknik pengambilan sampel pada umumnya dilakukan secara random, pengumpulan data menggunakan instrumen penelitian, analisis data bersifat kuantitatif/statistik dengan tujuan untuk menguji hipotesis yang telah ditetapkan.

Metode analisis kuantitatifmenggunakan analisis regresi linear berganda dan mengolah hasilnya dengan aplikasi SPSS 20. Persamaan Regresi linier berganda dikemukakan oleh Sugiyono (2013):

$$
Y=a+\beta_{1} X_{1}+\beta_{2} X_{2}+\beta_{3} X_{3}+\beta_{4} X_{4}+e
$$

Kemudian rumus ditransformasikan menjadi:

$$
\mathrm{PP}=\mathrm{a}+\beta_{1} \mathrm{MD}+\beta_{2} \mathrm{UM}+\beta_{3} \mathrm{TP}+\beta_{4} \mathrm{JK}+\mathrm{e}
$$

Keterangan:

$$
\begin{array}{ll}
\text { PPP } & =\text { Pendapatan Pedagang } \\
\mathrm{a} & =\text { Konstanta } \\
\text { MD } & =\text { Modal } \\
\text { UM } & =\text { Umur } \\
\text { TP } & =\text { Tingkat Pendidikan } \\
\text { JK } & =\text { Jam Kerja }
\end{array}
$$

\section{Uji Signifikansi Statistik Secara Simultan (Uji F)}

Uji-F bertujuan untuk menunjukkan apakah semua variabel bebas yang dimasukkan dalam model mempunyai pengaruh secara simultan terhadap variabel tidak bebas. Uji-F dapat dirumuskan sebagai berikut:

Dimana:

$$
F-\text { Test }=\frac{R^{2} /(K-1)}{\left(1-R^{2}\right) /(n-k)}
$$

$\mathrm{R}=$ Koefisien Determinasi

$\mathrm{K}=$ Banyaknya Variabel Bebas

$\mathrm{N}$ = Banyaknya Jumlah Observasi 
Dengan hipotesis yang digunakan sebagai berikut: Model analisis pengaruh modal, umur, tingkat pendidikan dan jam kerja terhadap terhadap pendapatan PKL di Jalan Basuki Rahmat sampai Jenderal H. Agus Salim. $\mathrm{H}_{0}=\alpha_{1} ; \alpha_{2} ; \alpha_{3} ; \alpha_{4}=0$; dimana modal, umur, tingkat pendidikan dan jam kerjasecara simultan tidak berpengaruh terhadap pendapatan PKL di Jalan Basuki Rahmat Sampai Jenderal H. Agus Salim. $\mathrm{H}_{1}$ $=\alpha 1 ; \alpha_{2} ; \alpha_{3} ; \alpha_{4} \neq 0$; dimana modal, umur, tingkat pendidikan dan jam kerjasecara simultan berpengaruh terhadap pendapatan PKL di Jalan Basuki Rahmat sampai Jenderal H. Agus Salim

Dengan kriteria pengambilan keputusan sebagai berikut:

- Jika Prob (F Statistik) < signifikansi level 0,05 $(\alpha=5 \%)$, maka Ho ditolak berarti $\mathrm{H}_{1}$ diterima.

- Jika Prob (F Statistik) > signifikansi level 0,05 ( $\alpha=5 \%)$, maka Ho diterima berarti $\mathrm{H}_{1}$ ditolak.

\section{Uji Signifikansi Statistik Secara Parsial (Uji T)}

Uji t-statistik digunakan untuk menguji signifikan variabel independen terhadap variabel dependen dalam persamaan secara parsial. Bila signifikan berarti secara statistik hal ini menunjukkan bahwa variabel bebas mempunyai pengaruh secara parsial terhadap variabel tidak bebas. Nilai t hitung dapat diperoleh dengan formula sebagai berikut:

Dimana:

$$
\mathrm{t}=\frac{\left(\beta_{i}-\beta\right)}{S_{b}}
$$

$\beta_{i} \quad=$ Koefisien variabel independen ke-i

$\beta \quad=$ Nilai hipotesis nol

$S_{b} \quad=$ Simpangan Baku (Standar Deviasi) dari variabel independen ke-i

Dalam studi uji-t yang digunakan adalah uji-t satu arah, hipotesis yang digunakan sebagai berikut: Model analisis pengaruh modal, umur, tingkat pendidikan dan jam kerja terhadap terhadap pendapatan pedagang kaki lima di Jalan Basuki Rahmat sampai Jenderal H. Agus Salim. $\mathrm{H}_{0}=\alpha 1 ; \alpha_{2} ; \alpha_{3} ; \alpha_{4}=0$; dimana modal, umur, tingkat pendidikan dan jam kerja secara parsial tidak berpengaruh terhadap pendapatan PKL di Jalan Basuki Rahmat Sampai Jenderal H. Agus Salim di Kecamatan Kota Baru Kota Jambi. $\mathrm{H}_{1}=\alpha 1 ; \alpha_{2} ; \alpha_{3} ; \alpha_{4} \neq 0$; dimana modal, umur, tingkat pendidikan dan jam kerjasecara parsial berpengaruh terhadap pendapatan PKL di Jalan Basuki Rahmat sampai Jenderal H. Agus Salim.

Dengan kriteria pengambilan keputusan sebagai berikut:

- Jika Prob (t Statistik) < signifikansi level 0,05 ( $\alpha=5 \%)$, maka Ho ditolak berarti $\mathrm{H}_{1}$ diterima.

- Jika Prob (t Statistik) > signifikansi level 0,05 $(\alpha=5 \%)$, maka Ho diterima berarti $\mathrm{H}_{1}$ ditolak.

\section{Analisis Koefisien Determinasi $\left(\mathbf{R}^{\mathbf{2}}\right)$}

Untuk mengetahui besarnya pengaruh variabel independent terhadap variabel dependent digunakan dengan analisis determinasi $\left(R^{2}\right)$. Koefisien determinasi $\left(R^{2}\right)$ pada 
intinya mengukur kebenaran model analisis regresi. Dimana analisisnya adalah apabila $\mathrm{R}^{2}$ mendekati angka 1 , maka variabel independen yaitu variabel modal, umur, tingkat pendidikan, semakin mendekati hubungan dengan variabel dependent sehingga dapat dikatakan bahwa penggunaan model tersebut dapat dibenarkan. Model yang baik adalah model yang meminimumkan residual berarti variasi variabel independ dapat menerangkan variabel dependennya dengan $\alpha$ sebesar diatas 0,75 (Hasan, 2002), sehingga diperoleh korelasi yang tinggi antara variabel dependent dan variabel independent.

Akan tetapi ada kalanya dalam penggunaan koefisien determinasi terjadi bias terhadap suatu variabel independent yaitu variabel modal, umur, tingkat pendidikan, dan jam kerja yang dimasukkan dalam model. Setiap tambahan satu variabel independent yaitu modal,umur, tingkat pendidikan, jam kerja menyebabkan peningkatan $\mathrm{R}^{2}$, tidak peduli apakah variabel yaitu modal,tingkat pendidikan, jam kerja, umur, tersebut berpengaruh secara signifikan terhadap variabel dependent yaitu pendapatan pedagang kaki lima (memiliki nilai t yang signifikan).

\section{HASIL PENELITIAN DAN PEMBAHASAN Karakteristik Sosial dan Ekonomi}

Karakteristik sosial ekonomi responden digunakan untuk menggambarkan keadaan atau kondisi responden yang dapat memberikan informasi tambahan untuk memahami hasil penelitian. Penyajian data deskriptif dalam penelitian ini bertujuan agar dapat dilihat profil dari data keadaan sosial ekonomi pedagang kaki lima yang digunakan dalam penelitian.

Tabel 1. Jumlah dan persentase pedagang kaki lima berdasarkan kelompok umur

\begin{tabular}{cccc}
\hline No & Umur rata-rata (Tahun) & Jumlah (Oramg) & Persentase \\
\hline 1 & $17-22$ & 13 & 27,66 \\
2 & $23-28$ & 8 & 17,02 \\
3 & $29-34$ & 7 & 14,89 \\
4 & $35-40$ & 6 & 12,77 \\
5 & $41-46$ & 8 & 17,02 \\
6 & $47-52$ & 4 & 8,51 \\
7 & $53-58$ & 1 & 2,13 \\
\hline \multicolumn{2}{c}{ Rata-Rata Umur } & $\mathbf{3 3 , 0 1}$ \\
\hline
\end{tabular}

Sumber: Data diolah, 2019

Tabel 1 memperlihatkan bahwa responden yang terbanyak terletak pada kelompok umur 17-22 tahun dengan persentase sebanyak 27,66 persen. Hal ini dikarenakan kelompok usia 17-22 tahun ini secara umum adalah kelompok usia tamatan Sekolah Menengah Atas, yang memilih menjadi pedagang kaki lima sebagai batu loncatan sebelum memasuki pekerjaan yang lebih layak atau juga pekerjaan formal. Dan untuk yang terkecil terletak pada kelompok umur 53-58 tahun dengan persentase sebanyak 2,13 persen.. Untuk rata-rata kelompok umur pedagang kaki lima yang menjual makanan dan minuman yang menjadi responden adalah 33,01 dan dibulatkan menjadi 33 persen. Sedangkan secara rata-rata, umur pedagang kaki lima yang berada di Jalan Basuki Rahmat sampai Jenderal H. Agus Salim Kecamatan Kota Baru berada pada kelompok usia produktif. 
Tabel 2. Jumlah dan persentase pedagang kaki lima berdasarkan kelompok jenis kelamin

\begin{tabular}{ccc}
\hline Jenis kelamin & Jumlah (Orang) & Persentase (\%) \\
\hline Laki-laki & 31 & 65,9 \\
Perempuan & 16 & 34,1 \\
\hline Jumlah & $\mathbf{4 7}$ & $\mathbf{1 0 0}$ \\
\hline
\end{tabular}

Sumber: Data diolah, 2019

Tabel 2 diatas menunjukan bahwa dominan pedagang kaki lima yang menjadi responden adalah laki-laki dengan persentase sebesar 65,9 persen sedangkan perempuan dengan persentase sebesar 34,1 persen.

Tabel 3. Jumlah dan persentase pedagang kaki lima berdasarkan kelompok status perkawinan

\begin{tabular}{cccc}
\hline No & Status Perkawinan & Jumlah (Orang) & Persentase (\%) \\
\hline 1 & Menikah & 30 & 63,8 \\
2 & BelumMenikah & 17 & 36,2 \\
\hline & Jumlah & $\mathbf{4 7}$ & $\mathbf{1 0 0}$
\end{tabular}

Sumber: Data diolah, 2019

Tabel 3 diatas menunjukan bahwa dari total 47 responden, yang mempunyai status perkawinan menikah yaitu dengan persentase sebanyak 63,8 persen dan yang mempunyai status perkawinan belum menikah yaitu dengan sebanyak 36,2 persen.

Tabel 4. Jumlah dan persentase pedagang kaki lima berdasarkan kelompok jumlah tanggungan keluarga

\begin{tabular}{cccc}
\hline No & Jumlah Tanggungan (Orang) & Jumlah (Orang) & $\begin{array}{c}\text { Persentase } \\
(\boldsymbol{\%})\end{array}$ \\
\hline 1 & 1 & 14 & 29,79 \\
2 & 2 & 4 & 8,51 \\
3 & 3 & 12 & 25,53 \\
4 & 4 & 10 & 21,28 \\
5 & 5 & 5 & 10,64 \\
6 & 6 & 2 & 4,25 \\
\hline \multicolumn{4}{c}{} \\
\hline
\end{tabular}

Sumber: Data diolah, 2019

Tabel 4 menunjukan bahwa jumlah tanggungan responden terbesar ada pada jumlah tanggungan 1 orang yaitu dengan persentase sebesar 29,79 persen. Lalu diikuti dengan jumlah tanggungan 3 orang yaitu dengan persentase sebesar 25,53 persen. Sedangkan jumlah tanggungan 6 orang menjadi yang terkecil dengan persentase sebesar 4,25 persen. Untuk rata-rata (Mean) dari responden menurut jumlah tanggungan adalah 2,87 persen.

Tabel 5. Jumlah dan persentase pedagang kaki lima berdasarkan kelompok tingkat pendidikan

\begin{tabular}{llcc}
\hline No & Pendidikan (Tahun Sukses) & Jumlah (Orang) & $\begin{array}{c}\text { Persentase } \\
(\boldsymbol{\%})\end{array}$ \\
\hline 1 & Tamat SD & 11 & 23,4
\end{tabular}




\begin{tabular}{rrcc}
2 & Tamat SMP/Sederajat & 12 & 25,5 \\
3 & Tamat SMA/Sederajat & 21 & 44,7 \\
4 & Perguruan Tinggi & 3 & 6,4 \\
\hline Jumlah & $\mathbf{4 7}$ & $\mathbf{1 0 0}$ \\
\hline & Rata-Rata & 10 Tahun \\
\hline
\end{tabular}

Sumber: Data diolah, 2019

Tabel 5 menunjukan data tentang tingkat pendidikan pedakang kaki lima yang menjadi responden. Jumlah tingkat pendidikan yang berhasil ditempuh terbesar adalah SMA/Sederajat dengan persentase 44,7 persen. Kemudian disusul oleh SMP/Sederajat dengan persentase 25,5 persen dan yang terkecil adalah Perguruan Tinggi dengan persentase 6,4 persen. Untuk rata-rata (Mean) dari responden menurut tahun sukses yang ditempuh tingkat pendidikan adalah 10,08 yang dibulatkan menjadi 10 tahun.

Tabel 6. Jumlah dan persentase pedagang kaki lima berdasarkan kelompok lamanya

\begin{tabular}{cccc}
\multicolumn{5}{c}{ jam kerja } & & \\
\hline No & Lamanya Jam Kerja (Jam) & Jumlah (Orang) & Persentase (\%) \\
\hline 1 & $6-7,2$ & 21 & 44,68 \\
2 & $7,3-8,5$ & 11 & 23,40 \\
3 & $8,6-9,8$ & 9 & 19,15 \\
4 & $9,9-11,1$ & 3 & 6,38 \\
5 & $11,2-12,4$ & 2 & 4,26 \\
6 & $\geq 12,5$ & 1 & 2,13 \\
\hline \multicolumn{5}{c}{}
\end{tabular}

Sumber: Data diolah, 2019

Tabel 6 menunjukan data bahwa lamanya jam kerja pedagang kaki lima yang menjadi responden terbesar adalah pada lamanya jam kerja $6-7,2$ jam dengan persentase 44,68 persen. Lalu disusul lamanya jam kerja 7,3 - 8,5 jam dengan persentase 23,40 persen. Dan yang jumlah jam kerja yang paling terkecil adalah jumlah jam kerja 13,8 - 15 jam yaitu dengan persentase 2,13 persen. Untuk rata-rata (Mean) dari responden menurut lamanya jam kerja adalah 8,02 dan dibulatkan menjadi 8 .

Tabel 7. Jumlah dan persentase pedagang kaki lima berdasarkan kelompok status pekerjaan

\begin{tabular}{cccc}
\hline No & Status Pekerjaan & Frekuensi & Persentase (\%) \\
\hline 1 & Utama & 45 & 95,74 \\
2 & Sampingan & 2 & 4,26 \\
\hline & Jumlah & $\mathbf{4 7}$ & $\mathbf{1 0 0}$
\end{tabular}

Sumber: Data diolah, 2019

Dalam tabel 7 hampir semua pedagang kaki lima yang menjadi responden status pekerjaan nya utama yaitu dengan persentase sebesar 95,74 persen dan sisanya dengan persentase 4,26 persen atau 2 orang menjadikan pedagang kaki lima sebagai pekerjaan sampingan. Dari 2 pedagang yang menjadikan pedagang kaki lima sebagai pekerjaan sampingan.

Berikut adalah data kelompok modal tetap Pedagang Kaki Lima yang menjadi responden dari hasil rumus statistik: 
Tabel 8. Jumlah dan persentase pedagang kaki lima berdasarkan kelompok modal tetap

\begin{tabular}{cccc}
\hline No & Jumlah Modal Tetap (Rupiah) & Jumlah (Orang) & $\begin{array}{c}\text { Persentase } \\
(\%)\end{array}$ \\
\hline 1 & $200.000-1.099 .999$ & 15 & 31,91 \\
2 & $1.100 .000-1.999 .999$ & 6 & 12,77 \\
3 & $2.000 .000-2.899 .999$ & 4 & 8,51 \\
4 & $2.900 .000-3.799 .999$ & 8 & 17,02 \\
5 & $3.800 .000-4.699 .999$ & 6 & 12,77 \\
6 & $4.700 .000-5.599 .999$ & 6 & 12,77 \\
7 & $\geq 5.600 .000$ & 2 & 4,25 \\
\hline \multicolumn{3}{c}{$\mathbf{2 . 7 1 1 . 7 0 1 , 6}$} \\
\hline
\end{tabular}

Sumber: Data diolah, 2019

Dari tabel 8 dapat diketahui bahwa responden terbanyak adalah dengan modal tetap Rp. 200.000 - Rp. 1.599.999 dengan persentase sebesar 42,55. Hal ini dikarenakan pada teorinya memang sektor informal mempunyai ciri-ciri modal yang kecil. Dan jumlah yang terkecil adalah modal tetap $\geq \mathrm{Rp} 5.600 .000$ dengan persentase 4,25. Untuk rata-rata dari responden menurut modal tetap adalah $\mathrm{Rp}$. 2.711.701,6 dibulatkan menjadi Rp. 2.712.000.

Tabel 9. Jumlah dan persentase pedagang kaki lima berdasarkan kelompok modal operasional (per hari)

\begin{tabular}{cccc}
\hline No & Jumlah Modal Operasional (Rupiah) & Jumlah (Orang) & $\begin{array}{c}\text { Persentase } \\
(\boldsymbol{\%})\end{array}$ \\
\hline 1 & $50.000-185.999$ & 19 & 40,43 \\
2 & $186.000-321.999$ & 19 & 40,43 \\
3 & $322.000-507.999$ & 7 & 14,89 \\
4 & $508.000-600.000$ & 2 & 4,25 \\
\hline & Jumlah & $\mathbf{4 7}$ & $\mathbf{1 0 0}$ \\
\hline \multicolumn{3}{c}{ Rata-Rata } & Rp. 238.085,11
\end{tabular}

Sumber: Data diolah, 2019

Dari data tabel 9 diatas, bahwa modal operasional terbanyak terletak pada Rp. 50.000 - Rp. 185.999 dan Rp. 186.000 - Rp. 321.999 dengan persentase sebesar 40,43 persen. Modal operasional terkecil terletak pada Rp. 508.000 - Rp. 600.000 dengan persentase sebesar 4,25 persen. Untuk rata-rata dari responden menurut modal operasional adalah Rp. 238.085,11 dibulatkan menjadi Rp. 240.000 perhari. Untuk modal operasional yang terbanyak terletak pada kelas yang paling kecil pada tabel. Hal ini dikarenakan ciri-ciri dari sektor informal yang tidak memerlukan modal yang besar dalam operasionalnya.

UMKM adalah unit usaha produktif yang berdiri sendiri, yang dilakukan oleh orang perorangan atau Badan Usaha disemua sektor ekonomi (Tambunan, 2012). Pada prinsipnya, pembedaan antara Usaha Mikro (UMi), Usaha Kecil (UK), Usaha Menengah (UM) dan Usaha Besar (UB) umumnya didasarkan pada nilai asset awal (tidak termasuk tanah dan bangunan), omset rata-rata pertahun atau njumlah pekerja tetap (Winarno, 2011).

Tabel 10. Jumlah dan persentase pedagang kaki lima berdasarkan kelompok pendapatan bersih (per bulan)

\begin{tabular}{cccc}
\hline No & PendapatanBersih (Rupiah) & Jumlah (Orang) & $\begin{array}{c}\text { Persentase } \\
(\boldsymbol{\%})\end{array}$ \\
\hline 1 & $1.050 .000-2.721 .999$ & 17 & 36,17
\end{tabular}




\begin{tabular}{|c|c|c|c|}
\hline 2 & $2.722 .000-4.393 .999$ & 25 & 53,20 \\
\hline 3 & $4.394 .000-6.065 .999$ & 2 & 4,25 \\
\hline 4 & $6.066 .000-7.737 .999$ & 2 & 4,25 \\
\hline 5 & $\geq 7.739 .000$ & 1 & 2,13 \\
\hline & Jumlah & 47 & 100 \\
\hline & Rata-Rata & \multicolumn{2}{|c|}{ Rp. 3.260.000 } \\
\hline
\end{tabular}

Sumber: Data diolah, 2019

Dari tabel 10 diatas diketahui bahwa pendapatan bersih pedagang kaki lima yang menjadi responden yang terbanyak adalah pada pendapatan Rp. 2.722 .000 - Rp. 4.393.999 dengan persentase 53,19 persen. Lalu diikuti oleh pendapatan Rp. 1.050.000 - Rp. 2.721.999 dengan persentase sebesar 36,17 persen. Untuk rata-rata dari responden menurut pendapatan bersih adalah Rp. 3.260 .000 perbulan. Angka ini berada diatas angka UMP Provinsi Jambi tahun 2018 yaitu sebesar Rp. 2.243.718. Untuk rata-rata dari responden menurut pendapatan kotor adalah Rp. 5.870 .000 per bulan. Angka ini berada diatas UMP Provinsi Jambi tahun 2018 yaitu sebesar Rp. 2.243.718. Dengan pendapatan dalam sehari sebesar rata-rata Rp. 360.000 per hari.

Tabel 11. Hasil uji regresi berganda

\begin{tabular}{|c|c|c|c|c|}
\hline No & Variabel & Nilai Koefisien & t hitung & Probabilita \\
\hline 1 & (Constant) & 454,302 & 0,333 & 0,741 \\
\hline 2 & Modal & 8,757 & 7,038 & 0,000 \\
\hline 3 & Umur & $-41,698$ & $-2,087$ & 0,043 \\
\hline 4 & Tingkat Pendidikan & 3,18 & 0,044 & 0,965 \\
\hline 5 & Jam Kerja & 263,888 & 2,429 & 0,020 \\
\hline
\end{tabular}

Sumber: Data diolah, 2019

Berdasarkan tabel di atas diperoleh persamaan regresi berganda sebagai berikut:

$\mathrm{PP}=454,302+8,757 \mathrm{MD}-41,698 \mathrm{UM}+3,180 \mathrm{TP}+263,888 \mathrm{JK}+\mathrm{e}$

Persamaan regresi tersebut mempunyai makna sebagai berikut: Konstanta nilai koefisiennya sebesar 454,302, artinya jika variabel modal, umur, tingkat pendidikan danjam kerja tidak mengalami perubahan atau tetap, maka pendapatan PKL sebesar Rp. 454,302 ribu. Nilai koefisien modal adalah 8,7575, hal ini menunjukkan adanya hubungan positif, jika variabel modal mengalami kenaikan sebesar Rp. 1.000, sementara umur, tingkat pendidikan danjam kerja dianggap tetap, maka akan menyebabkan kenaikan pendapatan PKL sebesar Rp. 8,757 ribu. Nilai koefisien umur adalah -41,698, hal ini menunjukkan adanya hubungan negatif, jika variabel umur mengalami kenaikan sebesar satu tahun, sementara modal, tingkat pendidikan danjam kerja dianggap tetap, maka akan menyebabkan menurunkan pendapatan PKL sebesar Rp. 41.698. Nilai koefisien tingkat pendidikan adalah 3,180, hal ini menunjukkan adanya hubungan positif, jika variabel tingkat pendidikan mengalami kenaikan sebesar satu tahun, sementara modal, umur danjam kerja dianggap tetap, maka akan menyebabkan peningkatan pendapatan PKL sebesar Rp. 3,180 ribu. Nilai koefisien jam kerja adalah 263,888 , hal ini menunjukkan adanya hubungan positif, jika variabel jam kerja mengalami kenaikan sebesar satu jam, sementara modal, umur dan tingkat pendidikan dianggap tetap, maka akan menyebabkan peningkatan pendapatan pedagang sebesar Rp. 263,888 ribu.

Uji F dilakukan untuk melihat keberartian pengaruh variabel independen secara simultan terhadap variabel dependen atau sering disebut uji kelinieran persamaan 
regresi. Untuk melakukan uji $\mathrm{F}$ dapat dilihat pada tabel anova dibawah ini:

Pada tabel 12 diperoleh nilai sig $=0,000<0,05$ ini berarti variabel independen modal, umur, tingkat pendidikan dan jam kerja secara simultan benar-benar berpengaruh signifikan terhadap variabel dependen pendapatan PKL. Maka dengan kata lain variabel-variabel modal, umur, tingkat pendidikan dan jam kerja, mampu menjelaskan besarnya variabel dependen pendapatan PKL.

Tabel 12. Hasil uji F statistik

\begin{tabular}{llrrrrr}
\hline & & \multicolumn{1}{c}{$\begin{array}{c}\text { Sum of } \\
\text { Squares }\end{array}$} & df & Mean Square & F & Sig. \\
\hline \multirow{3}{*}{1} & Regression & 126440199,687 & 4 & 31610049,922 & 17,695 &, $000^{\mathrm{b}}$ \\
& Residual & 75029587,547 & 42 & 1786418,751 & & \\
& Total & 201469787,234 & 46 & & & \\
\hline
\end{tabular}

Sumber: Data diolah, 2019

Hasil pengujian diperoleh nilai $t$ hitung untuk variabel modal sebesar 7,038. dengan tingkat keyakinan $(\alpha=5 \%) \mathrm{df}=(42)$ untuk pengujian diperoleh nilai $\mathrm{t}$ tabel 1,698 dari perhitungan tersebut dapat dilihat bahwa nilai $t_{\text {hitung }}$ lebih besar dari $t_{\text {tabel }}(7,038>$ 1,698), artinya Ho ditolak dan Ha diterima artinya modal berpengaruh signifikan terhadap pendapatan. Dengan demikian hipotesis yang menyatakan pengaruh modal terhadap pendapatan PKL di Jalan Basuki Rahmat sampai Jenderal H. Agus Salim Kecamatan Kota Baru tahun 2019 benar dan terbukti

Hasil pengujian diperoleh nilai $\mathrm{t}$ hitung untuk variabel umur sebesar -2,087. Dengan tingkat keyakinan $(\alpha=5 \%)$ df $=(42)$ untuk pengujian diperoleh nilai $t$ tabel 1,698 dari perhitungan tersebut dapat dilihat bahwa nilai $\mathrm{t}_{\text {hitung }}$ lebih besar dari $\mathrm{t}$ tabel $(-$ 2,087 > 1,698), artinya Ho ditolak dan Ha diterima artinya umur berpengaruh signifikan terhadap pendapatan. Dengan demikian hipotesis yang menyatakan pengaruh umur terhadap pendapatan pedagang PKL di Jalan Basuki Rahmat sampai Jenderal H. Agus Salim Kecamatan Kota Baru tahun 2019 benar dan terbukti.

Hasil pengujian diperoleh nilai $t_{\text {hitung }}$ untuk variabel tingkat pendidikan sebesar 0,044 dengan tingkat keyakinan $(\alpha=5 \%) \mathrm{df}=(42)$ untuk pengujian diperoleh nilai $\mathrm{t}$ tabel 1,698 dari perhitungan tersebut dapat dilihat bahwa nilai $t$ hitung lebih kecil dari $t$ tabel $(0,044<1,679)$, artinya Ho diterima dan Ha ditolak artinya tingkat pendidikan tidak berpengaruh signifikan terhadapendapatan. Dengan demikian hipotesis yang menyatakan pengaruh tingkat pendidikan terhadap pendapatan PKL di di Jalan Basuki 2019 tidak benar dan tidak terbukti.

Hasil pengujian diperoleh nilai $t$ hitung untuk variabel jam kerja sebesar 2,429. Dengan tingkat keyakinan $(\alpha=5 \%)$ df $=(42)$ untuk pengujian diperoleh nilai $\mathrm{t}$ tabel 1,698 dari perhitungan tersebut dapat dilihat bahwa nilai $t$ hitung lebih besar dari $t$ tabel $(2,429>1,679)$, artinya Ho ditolak dan Ha diterima artinya jam kerja berpengaruh signifikan terhadap pendapatan. Dengan demikian hipotesis yang menyatakan pengaruh jam kerja terhadap pendapatan PKL di Jalan Basuki Rahmat sampai Jenderal H. Agus Salim Kecamatan Kota Baru tahun 2019 benar dan terbukti.

Tabel 13 diatas dapat kita lihat model summary diketahui nilai $\mathrm{R}_{\text {square }}$ sebesar 0,628. Artinya sebesar 62,8 persen variasi pendapatan PKL dijelaskan oleh variabel bebas dalam model, sedangkan sisanya 37,2 persen dijelaskan oleh variabel lain diluar penelitian. 
Tabel 13. Hasil uji $\mathrm{R}^{2}$ square

\begin{tabular}{llrrr}
\hline Model & R & R Square & $\begin{array}{c}\text { Adjusted R } \\
\text { Square }\end{array}$ & $\begin{array}{c}\text { Std. Error of the } \\
\text { Estimate }\end{array}$ \\
\hline 1 &, $792^{\mathrm{a}}$ &, 628 &, 592 & 1336,56977 \\
\hline
\end{tabular}

Sumber: Data diolah, 2019

Pengujian diperoleh nilai $\mathrm{t}$ tabel 7,038 dari perhitungan tersebut dapat dilihat bahwa diperoleh nilai $t$ tabel 1,698 dari perhitungan tersebut dapat dilihat bahwa nilai $t$ hitung lebih besar dari $t$ tabel $(7,038>1,698)$, artinya Ho ditolak dan Ha diterima artinya modal berpengaruh signifikan terhadap pendapatan. Hal ini sependapat dengan teori yang dikemukakan oleh Hermawan (2008) menyatakan modal operasional merupakan input (faktor produksi) yang sangat penting dalam menentukan tinggi rendahnya pendapatan. Tetapi bukan berarti merupakan faktor satu-satunya yang dapat meningkatkan pendapatan. Dalam hal ini modal bagi pedagang juga merupakan salah satu faktor produksi yang mempengaruhi tingkat pendapatan. Besar kecilnya modal operasional yang dipergunakan dalam usahanya tentunya akan berpengaruh terhadap pendapatan yang diperoleh pedagang kaki lima. Agar usaha dagangnya berjalan dengan baik, diperlukan modal dagang yang cukup memadai.

Pengujian diperoleh nilai $\mathrm{t}$ tabel $-2,087$ dari perhitungan tersebut dapat dilihat bahwa nilai $\mathrm{t}$ hitung lebih besar dari $\mathrm{t}$ tabel $(-2,087>1,679)$, artinya Ho ditolak dan Ha diterima artinya umurpedagang berpengaruh signifikan terhadap PKL. Hal ini sependapat dengan teori yang dikemukakan olehSethuraman dalam Samosir (2015) mengatakan faktor umur untuk menentukan pendapatan PKL. Umur seseorang dapat menggambarkan produktivitas sehingga mempengaruhi pendapatannya.Jumlah responden berdsarkan umur pada penelitian ini menunjukkan bahwa semakin tua umur maka semakin sedikit menjadi pedagang. Semakin sediktnya pedagang yang berumur 40 tahun keatas menunjukkan bahwa semakin kecil pendapatan yang diterima ketika umur semakin tua.

Pengujian diperoleh nilai $\mathrm{t}$ tabel 0,044 dari perhitungan tersebut dapat dilihat bahwa nilai $\mathrm{t}_{\text {hitung }}$ lebih besar dari $\mathrm{t}_{\text {tabel }}(0,044<1,698)$, artinya Ho diterima dan Ha ditolak artinya tingkat pendidikan tidak berpengaruh signifikan terhadap pendapatan. Hal ini tidak sependapat dengan Artianto dalam Hart (1991) yang mengatkant Tingkat pendidikan yang dimiliki seseorang diduga akan mempengaruhi pendapatan yang diterimanya dalam bekerja. Pendidikan memberikan pengetahuan bukan hanya dalam pelaksanaan kerja, tetapi juga landasan untuk mengembangkan diri dalam memanfaatkan sarana dan prasarana demi kelancaran pekerjaan.

Pengujian diperoleh nilai $\mathrm{t}$ tabel 2,429 dari perhitungan tersebut dapat dilihat bahwa nilai $\mathrm{t}$ hitung lebih besar dari $\mathrm{t}$ tabel $(2,429>1,698)$, artinya Ho ditolak dan Ha diterima artinya jam kerja berpengaruh signifikan terhadap pendapatan. Hal ini sependapat dengan hasil penelitian Todaro (2004) membuktikan adanya hubungan langsung antara jam kerja dengan tingkat pendapatan. Setiap penambahan waktu operasi akan makin membuka peluang bagi bagi bertambahnya omzet penjualan. Hasil survei yang menunjukkan bahwa jam kerja berpengaruh terhadap pendapatan pedagang yaitu jam kerja yang sama pada setiap jenis usaha yang sama, setiap jenis usaha yang sama akan mempunyai jam kerja yang sama. PKL memulai jualannya dengan waktu yang sama dan tutup dengan waktu yang sama, sehingga dengan menambah jam kerja kan menambah pendapatan mereka (Darman, 2015).

Secara sederhana kegiatan formal dan informal dari penduduk bekerja dapat diidentifikasi berdasarkan status pekerjaan. Pekerja formal mencakup status berusaha 
dengan dibantu buruh tetap dan buruh/karyawan/pegawai, sisanya termasuk pekerja informal. Berdasarkan identifikasi ini, maka pada Agustus 2018 sebanyak 759,6 ribu orang (44,13 persen) penduduk bekerja pada kegiatan formal dan sebanyak 961,76 ribu orang $(55,87$ persen) bekerja pada kegiatan informal. Secara sederhana kegiatan formal dan informal dari penduduk bekerja dapat diidentifikasi berdasarkan status pekerjaan. Pekerja formal mencakup status berusaha dengan dibantu buruh tetap dan buruh/karyawan/pegawai, sisanya termasuk pekerja informal. Persentase pekerja informal mengalami penurunan baik dibanding kondisi Agustus 2017 maupun Februari 2018. Selama setahun terakhir, pekerja informal menurun dari 58,53 persen pada Agustus 2017 menjadi 55,87 persen pada Agustus 2018.

\section{KESIMPULAN DAN SARAN Kesimpulan}

Berdasarkan hasil dan pembahasan sebelumnya dapat ditarik beberapa kesimpulan penelitian sebagai berikut: Karakteristik pedagang kaki lima yang menjadi responden menurut umur rata-rata 33 tahun, jenis kelamin yang terbanyak yaitu lakilaki, status perkawinan terbanyak yaitu menikah, jumlah tanggungan keluarga sebesar 3 tanggungan, menurut tingkat pendidikan jumlah terbanyak yaitu SMA, dari lamanya jam kerja yaitu 8 jam waktu bekerja dalam sehari, berjualan sebagai pekerjaan utama, rata-rata modal tetap sebesar Rp. 2.212.000, modal operasional dengan rata-rata sebesar Rp. 250.000 perhari dan untuk pendapatan rata-rata Rp. 3.376 .000 perbulan.Hasil regresi menunjukkan bahwa variabel modal, umur, dan jam kerja berpengaruh signfikan terhadap pendapatan pedagang kaki lima.

\section{Saran}

Bertitik tolak dari hasil penelitian yang dilakukan dapat disarankan hal-hal sebagai berikut: Berdasarkan karakteristik pedagang kaki lima di sekitar Jalan Basuki Rahmat sampai Jenderal H. Agus Salim agar dapat meningkatan pendapatan maka pedagang yang baik untuk berjualan yaitu laki-laki maksimal berkisar umur 33 tahun dan memiliki pendidikan minimal SMA, lalu jam kerja berkisan lebih kurang 8 jam perhari dengan modal operasional minimal Rp. 250.000 perhari, dengan begitu pedagang akan meiliki pendapat berkisar Rp. 3.376.000 perbulan. Untuk meningkatkan pedagang PKL seharusnya pedagang meningkatkan modal dalam hal ini modal yang dimaksud adalah modal operasional, karena semakin besar modal maka semakin besar pendapatan, begitu jutga dengan umur pedagang maksimal adalah 33 tahun karena semakin tua umur pedagang maka semakin kurang maksimal pedagang berjualan dan menyebabkan menurunnya pendapatan. Kemudian dengan meningkatnya lama jam kerja, semakin lama jam kerja PKL berjualan maka semakin besar pendapatan PKL. Pendapatan pedagang kaki lima yang berjualan di Jalan Jendral Basuki Rahmat sampai Jalan H. Agus Salim di Kecamatan Kota Baru.

\section{DAFTAR PUSTAKA}

Arikunto, Suharsimi. (2006). Prosedur Penelitian Suatu Pendekatan Praktik. Rineka Cipta: Jakarta.

Damayanti, I. (2011). Analisis Faktor-Faktor Yang Mempengaruhi Pendapatan Pedagang Kaki Lima di Pasar Gede Kota Surakarta. Jurnal Ekonomi 
Pembangunan, 8 (6) 14-18.

Darman. (2015). Kehidupan Sosial Pedagang Kaki Lima di Kota Samarinda (Studi Kasus Penjual Jagung Rebus ditepian).Jurnal Sosiolog, 3(1) 41-59.

Hart, Keith. (1991). Sektor Informal.Urbanisasi, Pengangguran dan Sektor Informal di Kota. Yayasan Obor Indonesia: Jakarta.

Hasan, M. Iqbal, (2002). Pokok-pokok Materi Metodologi Penelitian dan Aplikasinya. Ghalia Indonesia: Bogor.

Hermawan, dkk. (2008). Pengembangan Kurikulum dan Pembelajaran.Universitas Terbuka: Jakarta.

Kamaluddin, R (1999). Pengantar Ekonomi Pembangunan. Lembaga Penerbit Fakultas Ekonomi Universitas Indonesia: Jakarta.

Marhaeni (2004). Ekonomi Sumberdaya Manusia. Universtas Udayana: Denpasar.

Sudarmini, Ni, Nyoman. (2006). Peranan Pekerja Perempuan dalam Menunjang Pendapatan Keluarga pada Industri Kecil dan Kerajinan Rumah Tangga di Kabupaten Gianyar. Jurnal Ekonomi Pembangunan, 6 (4) 11-15.

Sukirno, Sadono. (2005). Teori Pengantar Mikro Ekonomi Edisi Ketiga. PT Raja Grafindo Persada: Jakarta.

Sugeng, Haryanto. (2009). Peran Aktif Wanita dalam meningkatkan Pendapatan Rumah Tangga Miskin. Jurnal Sosiologi, 3 (1)30-35.

Sugiyono. (2013). Metode Penelitian Pendidikan Pendekatan Kuantitatif, Kualitatif, dan $R \& D$. Alfabeta: Bandung.

Todaro, Michael P. dan Stephen C. Smith. (2004). Pembangunan Ekonomi di Dunia Ketiga. Erlangga: Jakarta.

Umar, Husein (2002). Metodologi Penelitian. PT. Raja Grafindo: Jakarta.

Wicaksono. (2011). Pengaruh Modal Awal, Lama Usaha, Dan Jam Kerja Terhadap Pendapatan Pedagang Kios Di Pasar Bintoro Demak. Universitas Diponegoro: Semarang.

Winarno, W.W. (2011). Analisis Ekonometrika dan Statistika dengan EViews. Edisi UPP STIM YKPN: Yogyakarta. 